\title{
KEEFEKTIFFAN PERMAINAN ENGKLEK DALAM MENGEMBANGKAN KEMAMPUAN MOTORIK KASAR ANAK USIA DINI
}

\author{
Dwiana Asih Wiranti, dan Diah Ayu Mawarti
}

UNISNU Jepara

Email: wiranti@unisnu.ac.id

\begin{tabular}{|c|c|}
\hline Info Artikel & Abstract \\
\hline $\begin{array}{l}\text { Sejarah Artikel: } \\
\text { Diterima } 9 \text { Oktober } 2018 \\
\text { Direvisi } 6 \text { November } 2018 \\
\text { Disetujui } 26 \text { November } 2018\end{array}$ & $\begin{array}{l}\text { This research was aimed at 1) measuring the learning result of the early childhood's motor } \\
\text { ability between pretest and posttest, 2) analyzing the effectiveness of engklek game in the } \\
\text { development of gross motor ability for the early childhood; 3) describing the children's } \\
\text { responses on engklek game in the development of gross motor ability for the early } \\
\text { childhood. This research applied experimental design with one group pretest posttest } \\
\text { design in answering the problem statements of the research. The location of the research }\end{array}$ \\
\hline $\begin{array}{l}\text { Keywords: } \\
\text { engklek game, gross motor } \\
\text { ability, early chilldhood. }\end{array}$ & $\begin{array}{l}\text { was in RA Manbaul Ma'arif. The data analysis technique used to calculate the research } \\
\text { result was t-test. The research result shows that the result of gross motor ability is } \\
\text { improved after being given the treatment through engklek game. Engklek game is effective } \\
\text { in improving the children's hard motor ability. It is proven by the fact that most of the } \\
\text { children are in the criteria of Starting to Develop when pretest was conducted and the }\end{array}$ \\
\hline & $\begin{array}{l}\text { criteria of Developed Excellently after the posttest was conducted. In addition, the } \\
\text { traditional game especially engklek received the positive response from the early childhood } \\
\text { to be applied in the learning. }\end{array}$ \\
\hline
\end{tabular}

\begin{abstract}
Abstrak
Penelitian ini bertujuan untuk 1) mengukur seberapa besar hasil belajar kemampuan motorik kasar anak usia dini antara pretest dan postest. 2) menganalisis keefektifan permainan engklek dalam pengembangan kemampuan motorik kasar bagi anak usia dini; dan 3) mendeskripsikan respon anak-anak terhadap permainan engklek dalam pengembangan kemampuan motorik kasar bagi anak usia dini. Penelitian ini menerapkan meteode eksperimen dengan tipe one group pretest posttest design dalam menjawab rumusan masalah penelitian. Lokasi penelitian berada di RA Manbaul Ma'arif, Teknik analisis data yang digunakan untuk menghitung hasil penelitian menggunakan t-test. Hasil dari penelitian ini menunjukkan bahwa hasil kemampuan motorik kasar setelah dilakukan treatment melalui permainan engklek meningkat. Pernainan engklek efektif dalam meningkatkan kemampuan motorik kasar anak, terbukti dengan mayoritas anak berada pada kriteria Mulai Berkembang (MB) saat pretes dan kriteria Berkembang Sangat Baik (BSB) setelah dilakukan postes. Selain itu, permainan tradisional engklek mendapat respon yang positif dari anak usia dini untuk dapat diterapkan dalam pembelajaran. Saran yang berkaitan dengan hasil penelitian ini yaitu: guru dapat melatih anak dan mengembangkan model inovasi pembelajaran dengan menggunakan permainan engklek atau permaian tradisional lain untuk meningkatkan kemampuan motorik anak.
\end{abstract}

(C) 2018 Universitas Muria Kudus 
Wiranti, Dwiana Asih., dan Mawarti, Diah Ayu

KEEFEKTIFFAN PERMAINAN ENGKLEK DALAM MENGEMBANGKAN KEMAMPUAN ...

REFLEKSI EDUKATIKA : Jurnal Ilmiah Kependidikan, Nomor 9, Volume 1, Desember 2018, hlm. 66-74

\section{PENDAHULUAN}

Berinteraksi dengan teman sebaya sangat baik dilakukan oleh anak usia dini. Banyak manfaat yang akan diperoleh baik untuk melatih kecerdaasan maupun kemampuan sosial anak. Terlebih melalui sebuah permainan tradisional. Effendi (2015:3) menerangkan bahwa permainan tradisional mampu untuk menstimulasi perkembangan motorik anak. Hal ini disebabkan karena dalam pelaksanaan permainan tradional lebih banyak melibatkan kemampuan motorik seperti berjalan, melompat, tarik menarik, melempar, jongkok, menendang, bahkan berlari.

Akan tetapi, dewasa ini seiring dengan kemajuan teknologi minat anak dalam permainan tradisional mulai terkikis. Anak lebih banyak yang memilih bermain gadget atau sekedar bermain di dalam rumah menggunakan alat permainan yang lebih modern seperti puzzle, lego, atau boneka. Hal ini juga merupakan kegiatan permainan yang positif, tetapi jika tidak diimbangi dengan kegiatan di luar tentu akan terjadi ketidakseimbangan kemampuan motorik kasar anak dan motorik halus anak. Selain itu lambat laun permainan tradisional juga tidak akan dikenal anak bahkan bisa punah. Padahal, Rahmadhani (2017:5) dalam penelitiannya mempertegas bahwa permainan tradisional mempunyai unsur budaya yang terus berkembang dalam masyarakat dan mengandung aturan serta norma adat yang perlu dilestarikan secara turun temurun. Oleh sebab itu, Untuk menyeimbangkan hal tersebut orang tua bisa melakukan banyak strategi pengenalan permainan tradisional bagi anak usia dini. Mulai dari mengajarkannya langsung bersama anak dan teman sebanyanya atau mempercayakan kepada lembaga PAUD.

Menurut Suyadi (2014: 25), lembaga PAUD diselenggarakan untuk menyesuaikan tahap perkembangan anak dengan menitikberatkan pada bimbingan ke arah pertumbuhan dan perkembangan, baik koordinasi motorik halus, motorik kasar, kecerdasar emosi, kecerdasan jamak, maupun kecerdasaan spiritual sesuai dengan dengan cirri khas dan pertumbuhan anak usia dini. Beberapa kegiatan yang ada di lembaga PAUD berisi kemampuan dasar yang meliputi kemampuan kognitif, moral, seni, spiritual, bahasa, seni, sosial dan motorik. Aspek motorik menjadi salah satu tolok ukur capaian perkembangan keterampilan dan ketangkasan anak. Oleh sebab itu, untuk menggali kemampuan motorik anak menjadi bagian sangat penting dan diperhatikan oleh lembaga PAUD.

Lembaga PAUD menjadi salah satu lahan untuk memberikan stimulasi kepada anak usia dini dalam mengembangakan kemampuan motorik anak melalui permainan. Preschooler spends most of their play time in exploratory or practice play (Brewer 2007). Brewer berpendapat bahwa masa prasekolah merupakan masa dimana anak menghabiskan waktunya untuk bermain dalam upaya mengeksplorasi dunianya. Hal ini memperkuat bahwa permainan dapat menjadi alat untuk mengoptimalkan kemampuan anak khususnya kemampuan motorik.

Perkembangan motorik adalah proses seorang anak belajar untuk terampil menggerakan anggota tubuh (Sujiono 2014: 10). Dalam upaya mengembangan kemampuan motorik, anak-anak bisa belajar dari guru tentang bagaimana mereka mengenal beberapa gerakan yang dapat dilakukan untuk melatih ketangkasan, kekuatan, kecepatan, kelenturan serta ketepaatan koordinasi tangan dan mata. Guru bisa mengajarkan kepada anak-anak mengenai perkembangan kemampuan motorik yang meliputi kemampuan motorik halus dan kemampuan motorik kasar.

Gerakan motorik kasar contohnya berjalan, berlari, memanjat, menendang, melompat, dan jungkir balik serta berdiri dengan satu kaki. Sujiono (2014: 4) menjelaskan bahwa melatih gerakan motorik kasar bisa dilakukan, misalnya melatih anak berdiri di atas satu kaki. Melalui latihan ini, anak akan berlatih keseimbangan dan jika anak sudah mampu untuk berdiri di atas satu kaki maka kemampuan motorik kasar yang lainnya akan lebih dikuasai anak dengan baik. Misalnya, seperti berlari, jika anak belum mampu berdiri di atas satu kaki maka kemampuan berlari akan terpengaruh karena berarti anak tersebut masih belum dapat mengontrol keseimbangan tubuhnya.

Dalam upaya meningkatkan motivasi anak untuk melakukan gerak motorik perlu cara belajar yang menyenangkan. Salah satu cara bisa dilakukan oleh guru melalui permainan. Seperti pada penelitian yang telah dilakukan oleh Vernadakis (2015) yang menyimpulkan bahwa bermain merupakan dasar perkembangan kemampuan dasar motorik anak. Oleh sebab itu, melalui permainan tradisional juga akan dapat meningkatkan motorik anak. 
Wiranti, Dwiana Asih., dan Mawarti, Diah Ayu

KEEFEKTIFFAN PERMAINAN ENGKLEK DALAM MENGEMBANGKAN KEMAMPUAN ...

REFLEKSI EDUKATIKA : Jurnal Ilmiah Kependidikan, Nomor 9, Volume 1, Desember 2018, hlm. 66-74

Dekdikbud (1998) menjelaskan bahwa dalam proses belajar dan pelatihan motorik atau gerak tubuh dipengaruhi oleh faktor internal dan eksternal. Faktor internal muncul dari dalam diri anak itu sendiri, seperti tipe tubuh, motivasi, atau hal lain yang membedakan individu tersebut dengan yang lainnya. Kondisi eksternal mencakup faktor-faktor dari luar yang memicu perkembangan gerak seseorang, seperti kondisi lingkungan, metode pelatihan, bahkan lingkungan sosial budaya yang lebih luas. Oleh sebab itu, melatih gerak motorik haruslah memperhatikan faktor internal dan eksternal individu tersebut agar hasil optimal.

Kegiatan pengembangan kemampuan motorik anak sudah banyak dilakukan oleh guruguru di lembaga PAUD baik pengembangan motorik halus maupun kasar. Biasanya guru melaksanakan pembelajaran pengambangan kemampuan motorik halus di dalam kelas karena gerakan yang dilakukan anak-anak sebagian besar berpusat pada gerakan tangan. Sehingga lebih efektif dilakukan di dalam ruangan. Berbeda dengan pembelajaran motorik kasar. Guru harus lebih berhati-hati mengajarkan kepada anak agar bisa meminimalisir cidera pada anak. Selain itu, dalam upaya pengembangan kemampuan motorik kasar, guru harus berinovasi sekreatif mungkin agar anak-anak tertarik dan bersemangat melakukan kegiatan yang telah direncanakan. Dalam pengembangan kemampuan biasanya guru melakukan pembelajaran di luar ruangan agar anak bebas melakukan gerakan.

Inovasi pembelajaran dalam upaya pengembangan kemampuan motorik kasar bisa dilakukan melalui permainan tradisional. Selain untuk mengenalkan permainan tradisional kepada anak usia dini, cara ini juga bisa mendorong semangat siswa agar lebih semangat dan gembira dalam melakukan gerakan motorik kasar seperti berdiri dan melompat menggunakan satu kaki. Menurut hasil penelitian yang dilakukan oleh Charles (2017) yang melalukan penelitian tentang motorik di Malaysia menyimpulkan bahwa di Negara Malaysia, permainan tradisional berbasis intervensi dapat efisien dalam meningkatkan keterampilan motorik anak usia sekolah. Hal ini menguatkan bahwa permainan tradisional bisa digunakan untuk meningkatkan kemampuan motorik anak, dimana salah satu permainan tradisional tersebut adalah engklek.
Permainan engklek merupakan salah satu permainan tradisional yang dimainkan oleh dua anak atau lebih. Sebelum melakukan permainan, anak-anak biasanya membuat petak-petak untuk menjadi pijakan saat melompat dan masingmasing dari mereka memiliki koin atau benda yang dijadikan pion untuk mendeteksi sampai dimana perjalanannya terhenti. Cara mereka melompat tidak seperti melompat pada umumnya, melainkan melompat dengan satu kaki. Ketika melompat, anak-anak harus bisa berpijak pada kotak demi kotak tanpa diperbolehkan menyentuh garis tepi kotak. Selain itu, pemain juga harus memperhatikan apakah ada koin lawan dalam salah satu petak. Jika ada koin milik lawan maka kotak tersebut tidak boleh dilompati. Ini berarti pemain harus mampu melompati kotak berikutnya. Jika ternyata gagal melakukannya, maka anak tersebut harus berhenti bermain dan dilanjutkan oleh pemain berikutnya. Melihat teknik bermain yang demikian maka terlihat dengan jelas bahwa permainan engklek membutuhkan keterampilan gerak motorik kasar yakni melompat dengan satu kaki.

Kegiatan pembelajaran di RA Manbaul Ma'arif sering berada diruangan, untuk kegiatan jasmani biasanya ditempatkan di luar ruangan. Selain itu beberapa kegiatan pengembangan motorik kasar juga berada di luar ruangan. Akan tetapi sejauh ini, pendidik belum pernah mencoba melakukan kegiatan pengembangan kemampuan motorik kasar dengan menerapkan permainan engklek. Pendidik hanya mengajak siswa berjalan-jalan keliling sekolah atau berlari mengambil bola. Pendidik di RA Manbaul Ma'arif selama ini hanya membelajarkan lari, jalan, menendang bola, berjinjit dan melompat sambil bernyanyi. Pelaksaan pembelajaran dengan cara tersebut terus menerus dapat membuat anak - anak merasa jenuh dan bosan karena mereka sudah merasa terbiasa dan kurang tertantang. Akan lebih baik jika pengembangan kemampuan motorik kasar ini bisa lebih variatif, menyenangkan, serta dalam nuansa permainan. Selain itu bentuk gerakan juga berbeda, seperti melompat dengan satu kaki. Biasanya anak hanya diajari melompat, tetapi saat ini diajari melompat dengan satu kaki melalui permainan tradisional engklek. 
Wiranti, Dwiana Asih., dan Mawarti, Diah Ayu

KEEFEKTIFFAN PERMAINAN ENGKLEK DALAM MENGEMBANGKAN KEMAMPUAN ... REFLEKSI EDUKATIKA : Jurnal Ilmiah Kependidikan, Nomor 9, Volume 1, Desember 2018, hlm. 66-74

Berdasarkan hasil pengamatan yang dilakukan peneliti di RA Manbaul Ma'arif nampak bahwa pemanfaatan permainan tradisional belum optimal. Pemanfaatan permainan tradisonal di RA Manbaul Ma'arif masih kurang bervariasi. Selain itu, guru juga mengalami banyak kendala, diantaranya kurangnya kemampuan guru dalam menguasai teknik permainan tradisonal, kurang fasillitas, dan merasa kesulitan dalam menngkondisikan anak-anak. Dalam pelaksanaaannya permainan tradional ada yang menggunakan alat ada pula yang tidak menggunakan alat. Permainan tradisional yang sudah pernah diterapkan adalah bakiak dan jamuran. Sementara itu, permainan engklek belum pernah dilakukan dalam proses pembelajaran. Selain itu pula, peneliti melihat di sekolah ini masih mempunyai permasalahan pada kemampuan motorik kasar yang dimiliki anak. Sebagian besar anak kurang terlatih kemampuan motorik kasarnya karena berdasarkan wawancara dengan guru, beliau lebih sering mengajarkan atau melatih berlari, jongkok, dan berjalan-jalan serta melompat dengan satu kaki. Sementara untuk melompat dengan satu kaki belum pernah dilakukan.

Dengan menerapkan permainan engklek dalam mengembangkan kemampuan anak melompat dengan satu kaki, harapannya anak akan lebih tertantang, tertarik dan bersemangat melakukan gerakan tersebut. Berangkat dari kondisi demikian, maka peneliti akan menguji kefektifan permainan engklek dalam pengembangan kemampuan motorik kasar anak usia dini, serta bagaimanakah respon anak-anak RA Manbaul Ma'arif terhadap pembelajaran tersebut. Peningkatan kemampuan motorik tersebut dilakukan dengan mengamati kemampuan sebelum dan memberikan upaya peningkatan melalui penerapan permainan engklek menggunakan media engklek yang menarik dan mengarahkan cara bermain yang menyenangkan sehingga anak termotivasi untuk melakukan gerakan motorik kasar dengan lebih baik dari sebelumnya.

Penelitian Khasanah, dkk (2011) membuktikan bahwa permainan tradisional dapat menstimulasi aspek perkembangan anak seperti, fisik-motorik, kognitif, sosial emosial dan bahasa. Perbedaan penelitian ini dengan penelitian yang dilakukan oleh Khasanah, dkk terletak pada fokus penelitian. Penelitian Khasanah berfokus pada keterkaitan permainan tradisional bagi perkembangan anak secara menyeluruh, sedangkan penelitian ini berfokus pada keefektifan permainan engklek terhadap kemampuan motorik kasar anak. Berdasarkan uraian latar belakang tersebut dan kajian hasil penelitian, penelitian ini bertujuan untuk mengungkap kefektifan permainan engklek dalam pengembangan kemampuan motorik kasar anak usia dini di RA Manbaul Ma'arif Jepara.

\section{METODE PENELITIAN}

Desain penelitian yang digunakan dalam penelitian ini adalah desain penelitian eksperimen dengan tipe one group pretest posttest design. Pemilihan desain tersebut didasarkan pada kebutuhan penelitian yang akan dilaksanakan pada lembaga pendidikan, sehingga diambil desain dari tipe penelitien pre eksperimental. Dalam penelitian ini, anak-anak diuji melalui kegiatan pre test tentang kempuan anak dalam melakukan motorik kasar. Kemudian, setelah mengetahui hasil pretest, dilakukan kegiatan treatment melalui penerapan permainan engklek. Selanjutnya anak-anak kembali diuji dalam kegiatan post test.

Untuk memperjelas pelaksanaan dalam penelitian ini diperlukan adanya alur penelitian. Alur penelitian digunakan dalam penelitian ini adalah: 1) penentuan sampel dengan teknik purposive sampling; b) pengambilan data pretes; c) melakukan uji normalitas dan homogenitas; d) merancang kegiatan dalam memperlajaran dengan menerapkan permainan engklek dalam pembelajaran; e) menganalisis hasil pembelajaran yang menerapkan permainan engklek; dan f) menyusun hasil penelitian.

Populasi pada penelitian ini adalah anakanak di RA Manbaul Ma'arif. Selain itu, teknik sampel yang digunakan adalah purposive sampling. Teknik purposive sampling merupakan teknik pengambilan sampel dengan mempertimbangkan kriteria tertentu. Kriteria yang dipertimbangkan peneliti adalah anak-anak di RA Manbaul Ma'arif yang berusia 5-6 tahun.

Teknik pengumpulan data penelitian yang dirancang dalam penelitian ini adalah teknik observasi dan teknik tes lisan. Observasi digunakan untuk memberikan pengamatan pada kegiatan pretes dan postes. Uji prasyarat yang digunakan adalah uji normalitas dan homogenitas yang selanjutnya dilakukan teknik analisis data menggunakan uji beda ( $t$ test). Uji beda tersebut digunakan untuk mengukur hasil pretest dan posttest (Sugiyono, 2015). Selain itu, juga digunakan untuk membandingkan hasil pembelajaran antara pembelajaran yang menerapkan permainan engklek dan 
Wiranti, Dwiana Asih., dan Mawarti, Diah Ayu

KEEFEKTIFFAN PERMAINAN ENGKLEK DALAM MENGEMBANGKAN KEMAMPUAN ...

REFLEKSI EDUKATIKA : Jurnal Ilmiah Kependidikan, Nomor 9, Volume 1, Desember 2018, hlm. 66-74

pembelajaran konvensional. Uji beda yang dilakukan tersebut menggunakan paired sample $t$ test untuk membandingkan data antara sebelum dan sesudah perlakuan.
HASIL DAN PEMBAHASAN

A. Hasil Belajar Kemampuan Motorik Kasar antara Pretest dan Postest

Kelompok yang diberi perlakuan menggunakan engklek memiliki nilai mean sebelum dan sesudah sebesar 15,00 dan 20,25. Sehingga pada kelompok yang diberikan perlakuan menggunakan engklek mengalami peningkatan sebesar 4,75 poin.

Tabel 1. Data Paired Samples Statistics

Paired Samples Statistics

\begin{tabular}{|c|c|c|c|c|c|}
\hline & & Mean & $\mathrm{N}$ & Std. Deviation & Std. Error Mean \\
\hline \multirow[t]{2}{*}{ Pair 1} & sesudah & 20.25 & 24 & 6.229 & 1.272 \\
\hline & sebelum & 15.00 & 24 & 5.579 & 1.139 \\
\hline
\end{tabular}

Sumber: Data Hasil Penelitian

Adapun perolehan skor dan kriteria anak yang diberikan perlakuan menggunakan engklek saat pelaksanaan pretes dan postes disajikan dalam tabel berikut.

Tabel 2. Hasil Pretest dan Postes

\begin{tabular}{|c|c|c|c|c|c|c|}
\hline \multirow[t]{2}{*}{ Skor } & \multirow[t]{2}{*}{ Rentang nilai } & \multirow[t]{2}{*}{ Kriteria } & \multicolumn{2}{|c|}{ Pretes } & \multicolumn{2}{|c|}{ Postes } \\
\hline & & & $\bar{\sum}$ & $\%$ & $\sum$ & $\%$ \\
\hline 4 & $23-28$ & $\begin{array}{l}\text { Berkembang Sangat Baik } \\
\text { (BSB) }\end{array}$ & 5 & 21 & 12 & 50 \\
\hline 3 & $17-22$ & Sesuai Harapan (BSH) & 2 & 8 & 3 & 13 \\
\hline 2 & $12-16$ & Mulai Berkembang (MB) & 10 & 42 & 9 & 37 \\
\hline 1 & $7-11$ & Belum Berkembang (BB) & 7 & 29 & 0 & 0 \\
\hline
\end{tabular}

Sumber: Data Hasil Penelitian

Berdasarkan hasil tabel tersebut saat dilakukan pretes, sebanyak 7 anak (29\%) berada pada kriteria Belum Berkembang (BB), dimana 7 anak tersebut belum bisa melakukan lompatan dengan satu kaki. Sebanyak 10 anak (42\%) berada pada rentang Mulai Berkembang (MB). 10 anak tersebut sudah bisa melakukan melompat menggunakan satu kaki tetapi masih perlu adana bantuan. Seperti dipegangi guru atau sambil berpegangan pada benda disekitarna. Selanjutnya ada 2 anak (8\%) yang berada pada rentang Berkembang Sesuai Harapan (BSH), dimana anak sudah bisa melakukan gerakan tanpa bantuan, serta 5 anak (21\%) berada pada rentang Berkembang Sangat Baik (BSB). Kelima anak ini sudah lancar melakukan gerakan engklek.

Hasil postes menunjukkan bahwa tidak satupun anak yang berada pada kriteria BB. Ini artinya setelah dilakukan treatment, kemampuan motorik anak dalam melompat menggunakan satu kaki meningkat. Dimana semua anak sudah bisa melakukan gerakan tersebut. Meskipun, ada criteria lain yang belum sempurna 100\% meningkat. Ada 9 anak atau 37\% yang berada pada rentang MB. Maksudnya, 9 anak ini masih memerlukan bantuan ketika melakukan gerakan lompatan dengan satu kaki. Kemudian, sebanyak 3 anak (13\%) berada pada rentang BSH. Dikatakan sesuai harapan, karena pada kriteria ini anak telah mampu melakukan gerakan tanpa bantuan dan sesuai dengan aturan. Selanjutnya sebanyak 12 anak (50\%) berada pada rentang BSB, dimana anak sudah lancar melakukan gerakan, tanpa bantuan dan mampu melakukan gerakan sesuai dengan aturan.

Hal ini senada dengan hasil penelitian sebelumnya, Aulia (2018) bahwa Dalam penelitian yang dilakukan sebanyak lima kali pertemuan, peneliti menemukan adanya 
Wiranti, Dwiana Asih., dan Mawarti, Diah Ayu

KEEFEKTIFFAN PERMAINAN ENGKLEK DALAM MENGEMBANGKAN KEMAMPUAN ...

REFLEKSI EDUKATIKA : Jurnal Ilmiah Kependidikan, Nomor 9, Volume 1, Desember 2018, hlm. 66-74

perbedaan yang signifikan antara tahap pra-test dengan tahap post-test. Pada tahap pra-test semua anak belum bisa melompat dengan satu kaki, melempar sesuai dengan terarah, dan sebagian lagi sudah bisa meloncat dengan kedua kaki tanpa terjatuh. Setelah dilakukan treatment sebanyak empat kali pertemuan, peneliti menemukan bahwa ditiap - tiap pertemuan ada peningkatan yang berangsur - angsur membaik disemua indikator. Sehingga pada tahap post-test semua indikator perkembangan motorik kasar anak meningkat.

Dari hasil tersebut dapat disimpulkan bahwa mayoritas pada saat postes kemampuan anak berada pada kriteria Mulai Berkembang (MB) dan kriteria Berkembang Sangat Baik (BSB) saat dilakukan postes.

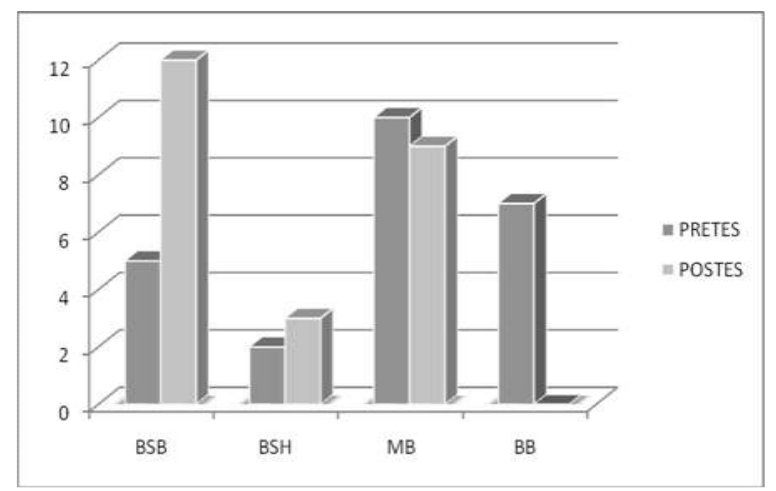

Gambar 1. Grafik Hasil Belajar pada saat Pretest dan Posttest.

Dari gambar grafik tersebut dapat diketahui bahwa hasil belajar anak setelah dilakukan treatment melalui permainan engklek meningkat. Dimana pada saat pretest persentase kemampuan anak paling banyak terletak pada kriteria mulai berkembang. Setelah dilakukan treatment, pada saat postes meningkat menjadi criteria berkembang sangat baik yang paling tinggi.

\section{B. Kefektikan Permainan Engklek dalam Pengembangan Motorik Kasar}

Selain dilakukan analisis deskriptif, hasil pembelajaran ini juga di analisis menggunakan paired sample $t$ test. diketahui hasil Sig. (2 tailed) menunjukkan hasil 0,000 . Interpretasi hasil tersebut apabila hasil signifikansi $<0,05$ maka $\mathrm{H}_{0}$ ditolak. $\mathrm{H}_{0}$ berbunyi bahwa tidak ada perbedaan rata-rata pretes dan postes. Sehingga didapat bahwa $0,000<0,05$ sehingga $\mathrm{H}_{0}$ ditolak. Penolakan $\mathrm{H}_{0}$ tersebut menyatakan bahwa ada perbedaan rata-rata hasil pretes dan postes.

Selain menginterpretasi hasil signifikansi, uji paired juga dapat digunakan untuk menginterpretasi nilai t. Apabila $t_{\text {hitung }}>t_{\text {tabel }}$, maka H0 ditolak. Berdasarkan tabel tersebut, didapat bahwa $\mathrm{t}_{\text {tabel }} 4,250>2,069$ sehingga simpulan yang sama didapat bahwa apabila $t_{\text {hitung }}$ $>\mathrm{t}_{\text {tabel }}$, maka $\mathrm{H}_{0}$ ditolak.
Berdasarkan data tersebut, dapat disimpulkan bahwa terdapat perbedaan rata-rata hasil pretest dan posttest. Dimana setelah dilakukan treatment, anak-anak melakukan posttest dan hasilnya menunjukkan adanya peningkatan kemampuan motorik kasar anak. Dibuktikan dengan anak yang telah mampu mencapai indikator keberhasilan kemampuan motorik. Seperti mampu melakukan gerakan keseimbangan. Dimana anak bisa melompat dengan satu kaki tanpa bantuan. Anak mampu melakukan gerakan terkontrol, dimana anak bisa mengontrol diri sendiri tanpa diingatkan. Melakukan gerakan manipulastif, melakukan gerakan fisik sesuai dengan aturan, serta terampil menggerakkan tangan dan kaki. Hal ini menunjukkan bahwa permainan engklek efektif dalam pengembangan kemampuan motorik kasar anak usia dini.

\section{Hasil Respon Anak}

Data respons anak-anak yang diambil dapat digunakan sebagai bahan pembanding bahwa perlakuan yang diberikan peneliti kepada anak-anak tidak jauh berbeda antar satu kelompok dengan kelompok lainnya. Adapun hasil respons anak-anak disajikan dalam bentuk tabel dan diagram. 
Wiranti, Dwiana Asih., dan Mawarti, Diah Ayu

KEEFEKTIFFAN PERMAINAN ENGKLEK DALAM MENGEMBANGKAN KEMAMPUAN ...

REFLEKSI EDUKATIKA : Jurnal Ilmiah Kependidikan, Nomor 9, Volume 1, Desember 2018, hlm. 66-74

Tabel. 3. Hasil Respon Anak

\begin{tabular}{lll}
\hline Kriteria & $\sum$ & $\mathbf{\%}$ \\
\hline Mau bermain engklek & 14 & $58,33 \%$ \\
Senang bermain engklek & 21 & $87,50 \%$ \\
Permainan engklek mudah & 14 & $58,33 \%$ \\
Main bersama teman & 22 & $92 \%$ \\
Bermain lagi & 17 & $70,83 \%$ \\
\hline
\end{tabular}

Sumber: Data Hasil Penelitian

Berdasar pada tabel, anak-anak yang diberikan kegiatan engklek memberikan respons $58,33 \%$ menyatakan mau jika diajak bermain engklek lagi, selanjutnya kriteria anak yang merasa senang bermain engklek sebanyak $87,50 \%$. Mereka merasa senang dengan alasan karena permainannya menarik, terlebih dilakukan di luar ruangan sehingga mereka lebih merasa nyaman. Kemudian, sebanyak 58,33\% anak-anak merasa mudah ketika melompat dengan satu kaki di dalam permainan engklek.
Dibandingkan harus melompat dengan satu kaki tanpa bermain engklek. Adapun kriteria anak yang memilih lebih senang bermain bersama teman sebesar 92\%. Hal ini menunjukkan bahwa anak lebih senang berkelompok daripada melakukan kegiatan secara individu. Terakhir, sebanyak 70,83\% anak berminat ketika diajak bermain lagi oleh peneliti mereka merasa senang bermain dengan orang baru dengan kegiatan yang menarik.

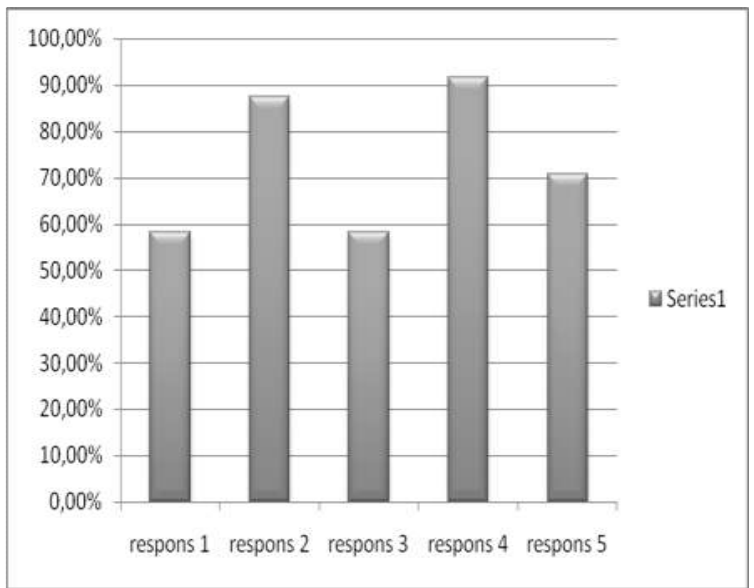

Gambar 2. Grafik Respon Anak

Hasil respons tersebut paling tinggi berada pada kriteria kenyamanan anak bermain bersama teman dalam melakukan kegiatan engklek dibandingkan bermain sendiri. Ini sangat relevan dengan karakter permainan engklek ang aakan lebih menarik dan efektif jika dimainkan secara berkelompok. Sementara itu, respons yang memiliki nilai paling rendah adalah kriteria mau atau tidaknya diajak bermain engklek lagi bersama peneliti. Sebagian besar anak tidak mau karena mereka merasa lelah jika bermain engklek berulang-ulang. Hal ini sangat wajar karena dalam bermain engklek membutuhkan tenaga, terlebih bagi ukuran anak usia dini. Mereka merasa lelah jika permainan diulang-ulang dalam satu waktu. Sementara itu, respon anak dalam menyatakan permainan engklek mudah juga mendapat persentase yang paling rendah. Dimana jumlah persentasena sama dengan jumlah persentase pada kriteria mau tidaknya anak diajak bermain engklek lagi yaitu sebesar 58,33\%. Meskipun sebagian besar anak menyatakan bahwa permainan engklek itu mudah, tetapi persentase ini masih tergolong pada kriteria yang mendapat persentase paling rendah.

Dari hasil respon anak ini dapat ditarik kesimpulan bahwa permainan engklek merupakan permainan yang mendapat respon baik bagi anak usia dini. Dimana melalui permainan engklek, anak merasa mudah dalam melakukan gerakan motorik kasar, merasa 
Wiranti, Dwiana Asih., dan Mawarti, Diah Ayu

KEEFEKTIFFAN PERMAINAN ENGKLEK DALAM MENGEMBANGKAN KEMAMPUAN ...

REFLEKSI EDUKATIKA : Jurnal Ilmiah Kependidikan, Nomor 9, Volume 1, Desember 2018, hlm. 66-74

senang dalam pembelajaran, merasa senang bermain berkelompok, dan ingin melakukan permainan engklek lagi. Hal ini berarti permainan tradisional khususnya engklek mendapat respon yang positif dari anak usia dini untuk dapat diterapkan dalam pembelajaran. Tidak hanya kemampuan motorik kasar anak saja namun juga dimungkinkan mengembangkan aspek - aspek perkembangan yang lainnya seperti aspek kognitif, bahasa, social dan emosional. Hal ini sesuai dengan hasil penelitian sebelumnya dari Munawaroh (2017), bahwa pengembangan model pembelajaran permainan tradisional engklek yang dilakukan dengan bermain sambil belajar yang bersifat inovatif, aktif, kreatif dan menyenangkan merupakan salah satu model pembelajaran yang dapat menstimulasi dan mengeksplorasi kemampuan kognitif, bahasa, social emosional, fisik motorik, dan seni.

\section{PENUTUP \\ Simpulan}

Hasil belajar anak pada kemampuan motorik kasar setelah dilakukan treatment melalui permainan engklek meningkat. Dimana pada saat pretest persentase kemampuan anak paling banyak terletak pada kriteria mulai berkembang. Setelah dilakukan treatment, pada saat postes meningkat menjadi criteria berkembang sangat baik yang paling tinggi.

Pernainan engklek efektif dalam meningkatkan kemampuan motorik kasar anak, terbukti dengan mayoritas anak berada pada kriteria Mulai Berkembang (MB) saat pretes dan kriteria Berkembang Sangat Baik (BSB) setelah dilakukan postes.

Permainan tradisional khususnya engklek mendapat respon yang positif dari anak usia dini untuk dapat diterapkan dalam pembelajaran.

\section{Saran}

Bagi guru diharapkan dapat melatih anak bermain permainan tradisional engklek sehingga dapat meningkatkan kemampuan motorik kasar anak. Guru diharapkan dapat mengembangkan model inovasi pembelajaran dengan menggunakan permainan tradisional lainnya, sehingga kemampuan motorik anak dapat terasah dengan baik dan mengetahui berbagai jenis permainan tradisional.

Bagi pengelola lembaga diharapkan memasukan permainan engklek sebagai salah satu program dalam pengembangan motorik kasar anak sehingga pengembangan motorik kasar anak bervariatif.
Bagi peneliti selanjutnya diharapkan untuk mengembangkan berbagai macam inovasi lain dalam permainan engklek ini. Selain itu bagi peneliti selanjutnya diharapkan untuk mengembangkan inovasi - inovasi permainan tradisional lain yang menarik dalam perkembangan yang lain selain dari motorik kasar.

\section{DAFTAR PUSTAKA}

Aulia, B. N. 2018. Mengembangkan Alat Permainan Trdisional Engklek Untuk Meningkatkan Motorik Kasar Anak Usia 4 - 5 Tahun Di PAUD MUTIARA HATI Tahun Ajaran 2017/2018. Jurnal Skripsi Universitas Mataram..

Brewer, Jo Ann. 2007. Introduction to: Early Childhood Education. United States of America: Pearson Education.

Charles, Md. Alli Gipit., Abdullah, Mohamad Razali.,\& Musa, Rabiu Muazu. 2017. The Effect Of Traditional Games Intervention Programme In The Enhancement SchoolAge Children's Motor Skills: A Preliminary Study. Movement, Health \& Exercise Journal, 6 (2), Hal 157-169.

Dekdikbud 1998. Belajar Keterampilan Motorik, Pengantar Teori dan Metode. Jakarta. Direktorat Jendral Pendidikan Tinggi.

Effendi, Dwi Imam, dkk. 2015. Permainan Tradisional sebagai Media Stimulasi Aspek Perkembangan Motorik Anak Usia Dini. Jurnal Didaktika, 13 (3).

Khasanah, dkk. 2011. Permainan Tradisional Sebagai Media Stimulasi Aspek Perkembangan Anak Usia Dini. Jurnal PAUDIA, 1 (1).

Munawaroh, Hidayatu. 2017. Pengembangan Model Pembelajaran dengan Permainan Tradisional Engklek. Sebagai Sarana Stimulasi Perkembangan Anak Usia Dini. Jurnal Obsesi 1 (2), Hal. 86 - 96.

Rahmadani, Ni Kadek A., Latiana, Lita., \& Agustinus, R. 2017. The Influence of Traditional Games on The Development of Children's Basic Motor Skills. Advances in 
Wiranti, Dwiana Asih., dan Mawarti, Diah Ayu

KEEFEKTIFFAN PERMAINAN ENGKLEK DALAM MENGEMBANGKAN KEMAMPUAN ...

REFLEKSI EDUKATIKA : Jurnal Ilmiah Kependidikan, Nomor 9, Volume 1, Desember 2018, hlm. 66-74

Social Science, Education and Humanities Research (ASSEHR) Journal, 169.

Sugiyono. 2015. Metode Penelitian Pendidikan. Bandung: PT ALFABETA.

Sujiono. 2014. Metode Pengembangan Fisik. Tangerang Selatan. Universitas Terbuka.
Suyadi. 2014. Teori Pembelajaran Anak Usia Dini: dalam kajian Neurosains. Bandung: PT Remaja Rosdakarya.

Vernadakis, Nikolaos., Papastergiou, Marina., \& Zetou, Eleni. 2015. The Impact Of An Exergame-Based Intervention On Children's Fundamental Motor Skills. Elsevier Computers \& Education journal, 83, hal. 90-102. 